\title{
PAVLOV'S SLEEP THEORY UNDER A NEW LIGHT*
}

\author{
TAKASHI HAYASHI** \\ Department of Physiology, School of Medicine, \\ Keio University, Tokyo
}

(Received for publication September 18, 1965)

\section{INTRODUCTION}

It was a great discovery in the history of physiology, when Pavlov found out that the experimental procedure of the conditioned reflex often induced a sleep in dog, as shown in Table 1 , which is taken from his book translated by Gantt. ${ }^{(6)}$

Table 1

Sleep and Hypnotic State from Inhibitory Conditioned Reflex Procedures (Pavlov)

\begin{tabular}{l|c|c|c|c}
\hline \hline State of dog & State of sleep & $\begin{array}{c}\text { Saliva } \\
\text { secretion }\end{array}$ & Food intake & Remarks \\
\hline Wakefulness & & + & + & \\
Sleep & $\left(\begin{array}{c}\text { I } \\
\text { II }\end{array}\right.$ & - & + & \\
III & $(-)$ & $(-)$ & deepest sleep \\
II & + & - & \\
Wakefulness & & - & + & \\
\hline
\end{tabular}

It was 1915 that he read the paper which contained Table 1 before St. Petersburg Biological Society. A quarter of a century later Hans Berger discovered the Electroencephalogram, ${ }^{(1)}$ and it was established by Bremer in France, ${ }^{(4)}$ and Magoun in U.S.A. (15) that man can confirm sleeping of animals

* Read before the Vth Meeting of conditioned Reflex in commemoration of I. P. Pavlov. Tokyo. 5th September 1965.

** Professor of Physiology. 
through the method of measuring EEG.

Since then sleep has been studied experimentally by this method, and an important aspect has been introduced by Jouvet in France ${ }^{(12)}$ (13) which he has named "paradoxical sleep."

Magoun mentioned that sleep has cortical EEG of a high voltage and slow wave, which is corresponding to the behavioral sleep of closed eyes and motionless posture. On the contrary, Jouvet showed that the paradoxical sleep has a low voltage and fast wave EEG in cortex as in alert state, with behavioral sleep of quite atonic body muscles with rapid eye movements. These descriptions remind us Pavlov's classification of sleep stages of Table 1. Does his stage of no secretory conditioned reflex with motion of food intake correspond to the sleep of high voltage and slow wave, and his stage of secretion with an atonic posture to the paradoxical sleep? Because the secretion of saliva has innate relation to cerebral cortex, ${ }^{(10)}$ but the muscle tone to subcortical integration. ${ }^{(8)}$ Thus Pavlov's theory of sleep deserves to be reexamined and reevaluated under these new disclosures.

Pavlov's sleep theory consists of the development of internal inhibition in cerebral cortex and its extension to subcortical structures and thence to the whole brain. What is the internal inhibition? With this question my study is concerned.

It was 1933 when I left Leningrad. It was April, but in Leningrad it was not yet spring. I walked along a snow lane of the Russian Academy of Science to the way to River Neva. A girl came running after me and said to me. "Your teacher wants to see you once more" I returned to Pavlov, around whom several persons were sitting and standing. "What work do you do after you will be back to Japan?" suddenly he said. I replied "On conditioned reflex by the method of measuring saliva, as you teached me, and-". "And?" "And in men" "Good, but if you want to do, try various chemicals and medicines to apply on conditioned reflex, as we are doing with caffein and bromides" I bowed and gave my promise to do so. It was the last time I have seen him, full of strength, brilliant teacher.

After coming back to Japan, I examined very many substances in dogs and later in men. Almost all substances reduced excitatory conditioned reflex, as well as inhibitory one, a few of them for example, nicotine, caffein and diphenylmethylaminopirin promoted excitation. But I have had none which promoted inhibitory conditioned reflex or extinctive inhibition, till I reached $\gamma$-amino$\beta$ hydroxybutyric acid (GABOB). 
1. $\gamma$ amino $\beta$ hydroxybutyrate deepens inhibition in the conditioned reflex

I have generally believed that this substance to be the inhibitory chemical transmitter in sensorimotor contex, ${ }^{(9)}$ therefore, I examined it on conditioned reflex as shown in Table 2. As was expected, this substance promoted the inhibition, in other words, it deepened the internal inhibition in the sense of Pavlov. This was the only substance which could promote the inhibitory conditioned reflex in dogs and in men.

Table 2

Enhaneement of Inhibition in Conditioned Saliva of an Experimental

Subject when GABOB is Intravenously Applied

\begin{tabular}{|c|c|c|c|c|}
\hline \multirow{2}{*}{$\begin{array}{l}\text { Positive } \\
\text { L ( } 40 \text { watt) }\end{array}$} & \multirow{2}{*}{$\begin{array}{l}\text { Negative } \\
M(120 / \mathrm{min})\end{array}$} & \multirow[b]{2}{*}{$\mathrm{L}+\mathbf{M}$} & \multicolumn{2}{|c|}{ Calculation $*$} \\
\hline & & & $\begin{array}{l}\text { Excitatory } \\
\text { process }\end{array}$ & $\begin{array}{l}\text { Inhibitory } \\
\text { process }\end{array}$ \\
\hline \multicolumn{5}{|c|}{$\begin{array}{l}\text { Messurements of established conditioned saliva } \\
(\mathrm{mm} . \text { in which resting saliva was reduced) }\end{array}$} \\
\hline+16.5 & -4.5 & +3.5 & +25.0 & -4.5 \\
\hline \multicolumn{5}{|c|}{$\begin{array}{l}5-10 \mathrm{~min} \text {. after an intravenous injection } \\
(1.0 \mathrm{ml} \text {. of } 5.0 \% \text { GABOB })\end{array}$} \\
\hline \multirow[t]{2}{*}{+9.5} & -6.5 & -3.5 & +9.5 & -13.0 \\
\hline & & & $\begin{array}{c}(62 \%) \\
\text { decrease }\end{array}$ & $\begin{array}{r}(188 \%) \\
\text { increase }\end{array}$ \\
\hline
\end{tabular}

* Calculation was due to the following equation;

$(\mathrm{L}+\mathrm{M})+\mathrm{k}=(\mathrm{L})+(\mathrm{M})$

if $\mathrm{k}$ is positive;

positive condition reflex $=\mathbf{L}+\mathrm{k}$

negative conditioned reflex $=\mathrm{M}$

if $\mathbf{k}$ is negative;

positive conditioned reflex $=\mathrm{L}$

negative conditioned reflex $=M+k$

Of course, GABOB, the inhibitory substance, comes from GABA which is also the mother substance to excitatory chemical transmitter, and recently our study of GABA has made a way to touch rhydroxybutyrate as shown in Table 3. In 1960 Bessman found that $\gamma$ hydroxybutyrate ( $\gamma \mathrm{OHbt}$ ) was a constituent of mammalian brain, as in concentration of $0.2-0.3 \mathrm{mM}$ in men and $1.0-2.0 \mathrm{mM}$ in rats. ${ }^{(2)}$ In 1964 , he discovered the related enzyme and at the same 
time, the metabolic pathway of this substance in brain. ${ }^{(5)}$

The fact that $\gamma \mathrm{OHbt}$ has a sleep producing action when intraperitoneally given in animals, has been known from around 1957 in France ${ }^{(14)}$ and in U.S.A., ${ }^{(3)}$ but it has not been known as a physiologically functional substance, because the threshold dose to induce sleep was very high, as $6.0-8.0 \mathrm{~g}$ for $10 \mathrm{Kg}$ weighed dogs and $12-14 \mathrm{~g}$ for $60 \mathrm{Kg}$ men.

\section{2. $\gamma$ hydroxybutyrate produces sleep through cerebrospinal fluid of dogs}

From our study as follows, it was proved that $\gamma \mathrm{OHbt}$ is one of real physiologically functional substances in brain.

1) When we introduced $\gamma$ OHbt into c.s.f. of dogs, it caused sleep with a latent period of $15-20 \mathrm{~min}$ as showen in Table 3.

Table $\$$

Sleep due to Injection of $\gamma$ OHbt into c.s.f. of Dogs

\begin{tabular}{c|c|c}
\hline Substance & Dose & Latent period, Continuation \\
\hline $\mathrm{OHCH}_{2} \mathrm{CH}_{2} \mathrm{CH}_{2} \mathrm{COOH}$ & $0.1 \mathrm{M} \quad 0.25 \mathrm{ml}$ & $\begin{array}{l}15-20 \mathrm{~min} \\
\text { lie down } \\
\text { eye closed sleeping } \\
\text { alert by sound }\end{array}$ \\
\hline
\end{tabular}

The concentration of the $\gamma \mathrm{OHbt}$ in the brain, when it induced sleep, was $0.00037 \%$. By contrast it was $0.13 \%$ when given via the circulation, it is presumed that blood brain barrier of this substance was very high.

2) Sleep which was caused by $\gamma \mathrm{OHbt}$ appeared to be natural behavioral sleep, from which dog was easily awaken by a touch of hand, a sound of clapping hands, and by calling his name, but soon he fell into a sleep again.

3) EEG of the sleep caused by $\gamma \mathrm{OHbt}$ was studied by several authors in Japan and it was confirmed that sleep due to $\gamma$ OHbt had two phases, high voltage slow wave sleep and alternately low voltage fast wave sleep which is like the paradoxical sleep in the sense of Jouvet.

What evidence have we that $\gamma \mathrm{OHbt}$ is generated from GABA in the brain? We have proved it in two ways. First because it could be obtained when metabolism of GABA into succinic acid was hinderd and the second one, when GABA's conversion into excitatory or inhibitory functional substance was hindered. (See Fig. 1.) 
Fig. 1 Three alternative metabolic pathways of GABA.

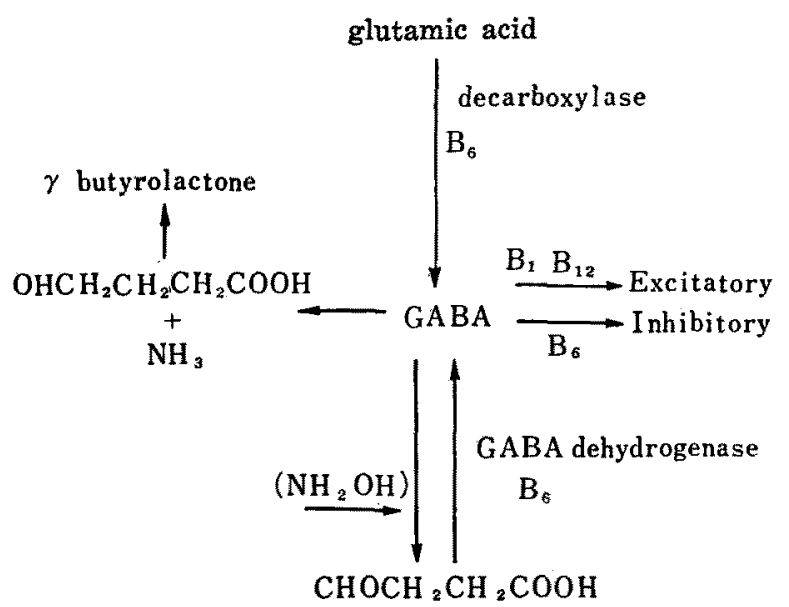

semialdehyde succinic acid

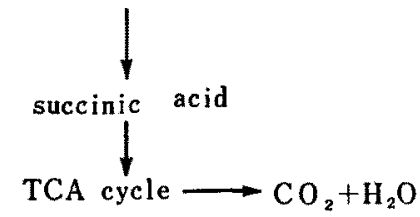

Table 4

Sleep due to Injections into c.s.f. of Dogs

\begin{tabular}{|c|c|c|c|}
\hline Substances & \multicolumn{2}{|c|}{ Dose } & Latent periods, continuation \\
\hline $\begin{array}{l}\text { succinic acid } \\
+ \\
\text { glutamic acid }\end{array}$ & $\begin{array}{l}0.1 \mathrm{M} \\
0.1 \mathrm{M}\end{array}$ & $\begin{array}{l}0.5 \mathrm{ml} \\
0.25 \mathrm{ml}\end{array}$ & $\begin{array}{l}15 \text { min } \\
\text { behavioxal sleep } \\
\text { alert by sound, snoring } \\
60 \text { min alert }\end{array}$ \\
\hline $\begin{array}{l}\text { succinic semialdehyde } \\
+ \\
\text { glutamic acid }\end{array}$ & $\begin{array}{l}0.1 \mathrm{M} \\
0.1 \mathrm{M}\end{array}$ & $\begin{array}{l}0.5 \mathrm{ml} \\
0.5 \mathrm{ml}\end{array}$ & $\begin{array}{l}20 \text { min } \\
\text { lie down } \\
\text { not sleeping } \\
50 \text { min alert }\end{array}$ \\
\hline $\begin{array}{l}\text { GABOB } \\
+ \\
\text { succinic acid } \\
+ \\
\text { glutamic acid }\end{array}$ & $\begin{array}{l}2 \mathrm{M} \\
0.1 \mathrm{M} \\
0.1 \mathrm{M}\end{array}$ & $\begin{array}{l}0.25 \mathrm{ml} \\
0.25 \mathrm{ml} \\
0.25 \mathrm{ml}\end{array}$ & $\begin{array}{l}3-4 \text { min lie down } \\
\text { eye closed } \\
\text { behavioral deep sleep } \\
1 \mathrm{~h} 15 \text { min alert }\end{array}$ \\
\hline $\begin{array}{l}\text { GABOB } \\
\text { glutamic acid } \\
\text { succinic acid }\end{array}$ & & & $\begin{array}{c}\text { no sleep } \\
" \prime \\
\prime \prime\end{array}$ \\
\hline
\end{tabular}


4) Actually when we introduced excessive succinic acid with glutamic acid to stop the deamination and to neutralize the produced $\mathrm{NH}_{3}$, the relation shown in Fig. 1 was expected to produce $\gamma \mathrm{OHbt}$ from GABA. It resulted to induce sleep as shown in Table 4.

5) When we inhibited the conversion of GABA into the inhibitory substance, by the introduction of excessive GABOB and the metabolization by the introduction of succinic acid, at the same time, glutamate to neutralize the produced $\mathrm{NH}_{3}$, the reaction of Fig. 1 moved to produce $\gamma \mathrm{OHbt}$ and resulted to induce sleep. Table 4 also showed the results.

3. $\gamma \mathrm{OHbt}$ is generated in the brain

The above experiments were all carried out in situ, and we could suggest how the results occurred. What is the direct proof, that $\gamma \mathrm{OHbt}$ is generated in the brain?

We took the homogenate of rats brain and after $30 \mathrm{~min}$ incubation, measured $\gamma \mathrm{OHbt}$ which was then chromatographically separated, by a gasanalyser. We found that normal brain tissue contained $0.06 \mu \mathrm{M} / \mathrm{g}$ of $\gamma \mathrm{OHbt}$ and after the introduction of succinic acid and glutamate it was $0.145 \mu \mathrm{M} / \mathrm{g}$.

These results are considered to be sufficient, from which to deduce that $\gamma \mathrm{OHbt}$ will be generated in daily life when the brain cells activity is lowered after a long hours functioning of the brain, thus, the circadian sleep occurs.

4. Sleep producing mechanism of $\gamma \mathrm{OHbt}$

How is the action of $\gamma \mathrm{OHbt}$ to induce sleep?

There are two possibilities, one is that $\gamma \mathrm{OHbt}$ reduces brain cells activity to stop it functioning as do some narcotics and toxic substances. The other is that $\gamma \mathrm{OHbt}$ is released from brain cells and is received by a special receptor of sleep inducing neural circuits and produces sleep. That the inhibition of midbrain reticular formation causes sleep is already known and supported much experimental evidences.

A question is, what route $\gamma O H b t$ takes to reach the receptors, since that $\gamma \mathrm{OHbt}$ is restrained by the blood brain barrier, it is unlikely that the route taken is via circulation.

The same problem has been discussed about neurosecretion. Neurosecretion first meant that there weve special neurons which liberate chemical substance 
at their endings which pass to the circulation, but the concept has been widened at present so that the term neurosecretion being used to refer to the secretion into the circulated body fluids by the ending of a neuron liberated chemical sublances that act on their cells some distant away.

In case of $\gamma$ OHbt the secretion is not from special neurons or at their endings but widely distributed brain cells, therefore it must be transported through c.s.f. Cerebrospinal fluid irrigates every corner of its spaces, and it is not difficult to look for the receptors to produce paradoxical sleep.

\section{Mechanism of paradixical sleep to be induced by $\gamma \mathrm{OHbt}$}

Paradoxical sleep consists of three main symptoms, one is quite atonic posture, the second is quick eye movements and the third is low voltage fast wave in the cortical EEG.

The tone of body muscles, especially of antigravity muscles is controlled by a special neural circuit. Sherrington first demonstrated that if one severs the brainstem on the level of colliculus superior, the animal displays decerebrate rigidity. ${ }^{(19)}$ This phenomenon has been studied by many authors, but the exact localization of the inhibition centre, at the same time, the tone centre has been not known.

1) We have succeeded to produce rigidity by longitudinal $2 \mathrm{~mm}$ width severing at the level of colliculus superior combined by horizontal same width severing in the midline from left to right as shown in Fig 2. The each severing produced rigidity, and the centre of inhibition of the rigidity must be in the crossing of these two band severings. It was the limited central grey mater around the Sylvian aqueduct, localised at $2 \mathrm{~mm}$ thick rings around the aqueduct.

2) What is the inhibitory pathway from that centr? We have confirmed by limited sectining that the pathway separates on bothsides beneath the middle and runs down along the curvature of the pontile swelling to reach the vestibular nuclei, which have been proved to be the centre for promoting muscle tone on bothsides of the body.

3) If we destruct the vestibular nuclei on both sides, the all body muscles suddenly lose their tone. Thus the origin of the loss of tone in paradoxical sleep may be due to the inhibition of this center by $\gamma \mathrm{OHbt}$.

4) The nucleus vestiburalis contains not only Deiter's nucleus but the medial and superior nuclei, which are connected with cranial nerves nuclei of 
The decerebrated surface of the midbrain of dog.

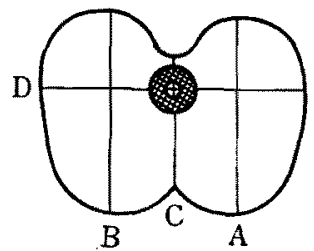

$\mathrm{C}$-longitudinal line

$\mathrm{D}$-lateral line

The transparent figure of pons from the behind of brain stem of dog.

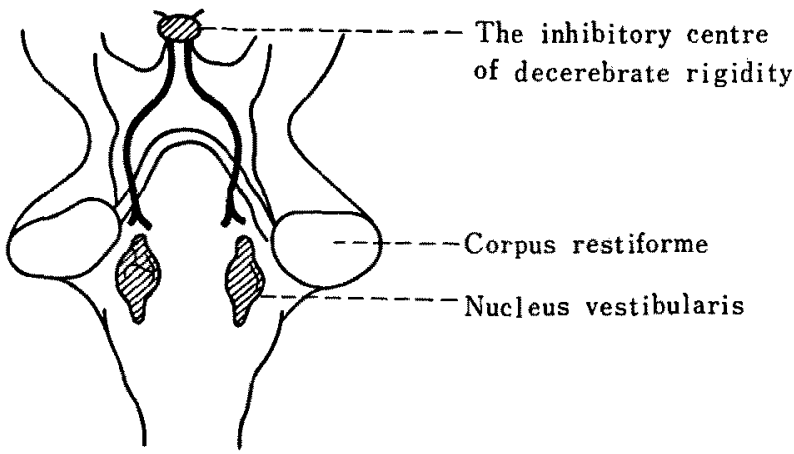

Fig. 2 Pontile tone centre of antigravity muscles and midbrain inhibitory centre of dogs.

eye movements in one hand, and on the other hand they are connected with cerebellum of which partial destruction causes involuntary eye movements. ${ }^{(20)}$ Therefore, when $\gamma$ OHbt reaches the pontile brain and affects the vestibular nuclei, and at the same time inhibit the connection with cerebellum, the loss of tone in body muscles with or without eye movements will appear.

5) If the involuntary eye movements occur, naturally the muscles of the eye will send afferent feed back to cerebral cortex in the special representations, at the same time, the affernt pathway to the reticular formation to be conducted through diffuse ascending system in the sense of Magoun. According to him the high voltage slow wave of sleep will be changed into low voltage rapid wave by the stimulation of the raticular formation.

As for the consiousness in sleep we can divide several stages of sleep. Sleep by the inhibition of reticular formation is considered as cortical sleep correspondent with Pavlov's first stage (see Table 1) in which conditioned saliva 


\section{PAVLOV'S SLEEP THEORY UNDER A NEW LIGHT}

exists but the eating activity is impaired. At the stage correspondent with Pavlov's second stage, $\gamma$ OHbt descends to the pontile brain, and manifestations of paradoxical sleep are elicited and consciousness should be more deeply impaired. For the third stage of Pavlov, it means that the inhibition reaches all centrencephalon with total loss of consciousness. ${ }^{(17)}$

\section{DISCUSSION}

The new interpretation of Pavlov's theory of sleep does have any contradictions as the inhibition theory?

The only contradiction comes from Hess' experiments where the stimulation of the III ventricle's wall causes sleep and means that the origin of sleep to be from the excitation of special neural centre. ${ }^{(11)}$ It contradicted to the inhibition theory.

Hess' experiment has been confirmed by many authors and at present it is summarised as follows; the stimulation of 4-8 per second electrice pulses causes sleep, but 40-60 per second pulses causes arousal state, owing to the sleep and wakefulness centre probably are situated close by each other. It is rather ambiguous.

It is not strange that the arousal reaction will be produced by the excitation at the wall of III ventricle, for there must exist every where any excitable neurons which will be stimulated by current spread when the stimulation was frequent and strong. The question is; what does the stimulation of 4-8 per second? Our tentative suggestion is as follows; Hypothalamus contains much $\gamma \mathrm{OHbt}$ since its contents of $\mathrm{GABA}$, and if $\gamma \mathrm{OHbt}$ connected with globulin or other nervous component, the low frequency pulses must release $\gamma \mathrm{OHbt}$ there. I have had an experiment that glutamic acid mixed with a diluted globulin in vitro would be easily separated by low frequency electrical pulses through it mainly to its negative side. ${ }^{(7)}$

Recently Péon showed that local application of Acetylcholine to frontal brain and many other sites produces sleep. ${ }^{(18)}$ He considers that there are two different neuronal systems, hypnogenic and the other an arousal vigilance system. Each system, produces its function by stimulation of electric or chemical locally applied. This is also antagonist to the inhibition theory. But it is not clear by his experiment that these substances act as excitatory or inhibitory.

Page pointed that serotonin induces sleeplike relaxation when applied to rabbits. (16) We examined by the introduction of serotonin into c.s.f. of dogs 
and confirmed that it did not produce relaxation, rather excitation.

These problems need further experimentation.

\section{REFERENCES}

1. Berger, H.: Ueber das Elektroenkephalogramm des Menschen. J. Psychol. Neurol. 40: 160-179, 1930.

2. Bessman, S. P. and Fishbein, W. N.: Gamma-Hydroxybutyrate, a normal brain metabolite. Nature, No. 4912, 1963.

3. Blunmenfeld, M., Suntay, R. G., and Hormel, M. H.: Sodium Gamma-Hydroxybutric acid. Anesthesia and Analgesia 41: 721-726, 1962.

4. Bremer, F.: Cerveau "isole" et physiologie du sommeil C. R. Soc. Biol. 118: 1235-1241, 1935.

5. Fishbein, W. N. and Bessman, S. P.: $\gamma$ Hydroxybutyrate in mammalian brain. J. Biol. Chem. 237: 357, 1964.

6. Gantt, W. H.: Lectures of conditioned reflex by Ivan Petrovitch Pavlov, New York, International Publishing Co., Inc., 1928, pp. 251.

7. Hayashi, T.: A suggestion of the mechanism how electric current excites the nervous system. Keio J. Med., 2: 23-28, 1953.

8. Hayashi, T.: Neurophysiology and Neurochemistry of Convulsion xiv +306 , Tokyo, Dainihon-Tosho Co., Ltd. 1959.

9. Hayashi, T.: The inhibitory action of beta-hydroxygamma-aminobutyric acid upon the seizure following stimulation of the moter cortex of dogs. J. Physiol. Lond. 145: 570-578, 1959.

10. Hayashi, T., Suhara, R., Takashita, H., and Ohkame, K.: Mechanism of secretion of resting saliva in men. Keio J. Med. 14: 19-25, 1965.

11. Hess, W. R.: Der Schlaf. Klin. Wschr. 12: 129-134, 1933.

12. Jouvet, M.: Telencephalic and rhombencephalic sleep in the cat. In: A CIBA Found. Symposium on the Nature of Sleep, 188-206, 1961.

13. Jouvet, M.: Paradoxical Sleep; A study of its Nature and Mechanisms. In: Sleep Mechanisms. Progress in Brain Research 18: Amsterdam Elsevier Publishing Company, 1965, 20-62.

14. Laborit, H., Bruce, F., Jouany, J. M., Gerard, J., and Fabiani, F.: Generalitée concernant létude experimentale de lémploi clinique du gamma-hydroxybutyrate de Na. Aggressologie 1: 407, 1960.

15. Magoun, H. W.: The waking brain. Springfield, Ill., 1958, viii +138.

16. Page, I. H. and McIsaac, W. M.: Serotonin. In: Neurochemistry, Charles C. Thomas Publisher., U.S.A., 1962, 620-635.

17. Penfield, W. and Jasper, H. H.: Epilepsy and the Functional Anatomy of the Human Brain. Boston, Little Brown and Co., 1954, 896.

18. Péon, P. H.: Central neuronal transmission in sleep and wakefulnes. In: Sleep Mechanisms. Progress in Brain Research 18: Amsterdam, Elsevier Publishing Company, 1965, 96-117.

19. Sherrington, C. S.: The integrative action of nervous system. London, Constable and Co., Ltd., 1906.

20. Takebayashi, H., Arimoto, K., Kawashima, K., Tsukiyama, K., Maeshima, S., and Oya, T.: Superior colliculus and vestibular system with special consideration of caloric and postrotatory nystaggmus. Wakayama Med. Reports: 6: $11-21,1961$. 